on the 1st day in the remnant of the amputated liver, were transferred intact to, and divided over, the daughter cells of the multiplying hepatocytes. Fouts et al. ${ }^{7}$ reported equal activities of side chain oxidation for hexobarbital between the 2nd and 8 th day after partial hepatectomy, but a comparison with the 1st day is not possible from their data and no liver weights were given. Their report of a sharp decrease in hexobarbital sleeping time between the $3 \mathrm{rd}$ and 5 th day, in conflict with our results, remains therefore unexplained ${ }^{8}$.

Résumé. La prolongation de l'anesthésie au pentobarbital fut constatée chez les rats pendant 1 semaine après l'hepatectomie partielle. Dans la suite, l'effet disparut. Le poids du foie était redevenu presque normal dès le 4ème jour. Les tissus hépatiques nouvellement formés ont donc été temporairement incapables de métaboliser le barbiturique.

J. M. Peters, C. J. Krijnen, and H. D. McEWEN

Department of Pharmacology, Queen's University, Kingston (Ontario, Canada), July 25, 1966.

5 J. W. Grisham, Cancer Res, 22, 842 (1962).

6 N. R. Klinman and A. J. Lrstev, Proc. Soc. exp. Biol. Med. 112, 338 (1963).

7 J. R. Fouts, R. L. Dixon, and R. W. Shultice, Biochem. Pharmac. 7,265 (1961).

8 The authors wish to thank Dr. E. M. BOYD, for professional advice. The project was assisted by a grant from the Medical Research Council of Canada. First author (J. M. PETERS) is a Fellow of the Medical Research Comeil of Canada.

\section{Effect of Insulin on Carbon Dioxide Production in Adipose Tissue from Immature Rats}

The purpose of this study was to determine the effect of immaturity on insulin-induced carbon dioxide production in rat epididymal fat pads. GLIEMANN ${ }^{1}$ has recently reported that conversion of glucose-1- $\mathrm{C}^{14}$ to carbon dioxide in adipose tissue is greater in rats weighing $100-110 \mathrm{~g}$ than in those weighing $200-230 \mathrm{~g}$. He also demonstrated relatively poor $\mathrm{CO}_{2}$ production in older rats, an observation previously reported by HAGEN, BALL, and COOPER ${ }^{2}$. The direct relationship between $\mathrm{CO}_{2}$ production and lipogenesis in adipose tissue has been shown by WINEGRAD and RENOLD ${ }^{3}$.

It has also been known for some time that rats and rabbits are capable of synthesizing fatty acids in utero, ${ }^{4,5}$, but relatively little is known about fat metabolism in immature animals. Such data may prove to be important from the standpoint of human pharmacology, since it may eventually help to explain some of the differences between children and adults in response to drugs. The present report concerns the effect of insulin on $\mathrm{CO}_{2}$ production in adipose tissue taken from young rats weighing $35-90 \mathrm{~g}$. For purposes of comparison, a small number of experiments were performed using adult rats weighing $150-200 \mathrm{~g}$.

Material and methods. The technique employed was essentially that described by BALL, MARTIN and COOPER ${ }^{\theta}$, in which $\mathrm{CO}_{2}$ production is measured manometrically in the Warburg apparatus. Male Sprague-Dawley rats were stunned by a blow on the head and decapitated by guillotine. Epididymal fat pads were removed, weighed, and transferred immediately to flasks containing $2.3 \mathrm{mI}$ of calcium-free Krebs-Ringer bicarbonate solution at $\mathrm{pH} 7.4$. Incubation, with shaking, was carried out for $30 \mathrm{~min}$ at $37.5^{\circ} \mathrm{C}$. Glucose, $0.1 \mathrm{ml}$, and glucogon-free insulin ?, $0.1 \mathrm{ml}$, were then added from the side-arm, resulting in a final concentration of $4 \mathrm{mg} / \mathrm{ml}$ and $0.1 \mathrm{U} / \mathrm{ml}$ respectively. Incubation was allowed to proceed for an additional $60 \mathrm{~min}$, and the positive (or negative) pressure readings appearing in $\mathrm{mm}$ on the manometers were converted to $\mu \mathrm{l}$ of $\mathrm{CO}_{2}$ evolved per $100 \mathrm{mg}$ of wet tissue/h. Pressure readings prior to addition of the side-arm contents were not used in the calculations, but were obtained to assure that a net positive production of gas was not occurring in the absence of insulin.

Rats were grouped according to weight as follows:

\section{Group}

I Immature

II Immature

III Immature

IV Adult

\author{
Weight \\ 35 through $50 \mathrm{~g}$ \\ 55 through $70 \mathrm{~g}$ \\ 75 through $90 \mathrm{~g}$ \\ 150 through $200 \mathrm{~g}$
}

An effort was made to allow each flask to contain roughly $100 \mathrm{mg}$ of adipose tissue. 2 or more rats from group I were usually required to fill 1 flask, whereas the tissue from 1 adult rat was always sufficient to fill 2 or more flasks. For the adult group, the average value of the flasks representing the tissue from one rat was considered as 1 experiment. This was done in order to justify the assumption (for statistical analysis) that the values obtained were independent of each other.

All animals in groups II, III, and IV were fed water and Purina Laboratory Chow ad lib. Group I rats were fed as follows: Ia same as groups II, III, and IV; Ib same, except that the pellets were crushed to make the ration more readily obtainable; and, Ic milk and milk-soaked bread.

Results. The results are presented in the Table. The data from group $\mathrm{Ia}$ is not included in the Table. Since rats of this size are for the most part newly weaned, it was felt that their relatively poor performance (5.4 $\mu \mathrm{l} \mathrm{CO}$ \pm 6.3 S.D., in 11 experiments) might be partially due to mechanical difficulty in obtaining adequate food from the

1 J. Gliemann, Diabetes 74, 643 (1965).

a J. M. HAGEN, E. G. BALL, and O. Cooper, J. biol. Chem. 234, 781 (1959).

3 A. 1. Winegrad and A. E. Renold, J. biol, Chem. 233, 267 (1958).

4 W. H. Goldwater and D. Stetren JR., J. biol. Chem. 169, 723 (1947).

"G. POrjak and M.-L. Befekmans, Biochem. J. 46, 547 (1950).

"E. G. BalL, D. B. Martin, and O. Cooper, J. biol. Chem. 234, 774 (1959).

7 Kindly supplied by Eli Lilly \& Company. 
regular pellets. It was found that $\mathrm{CO}_{2}$ production was increased somewhat by feeding either the crushed pellets $\left(11.2 \mu 1 \mathrm{CO}_{2} \pm 5.9\right.$ S.D., in 14 experiments) or milk-soaked bread (13.2 $\mu \mathrm{l} \mathrm{CO} 2 \pm 3.2$ S.D., in 6 experiments). There was no statistical difference between groups $\mathrm{Ib}$ and Ic $(\alpha=0.5)$ and these are therefore considered as one group of 20 experiments.

It can be seen that $C O$, production increased directly with weight up to $90 \mathrm{~g}$. Using KRAMER's multiple range test 8 , group III values were found to be significantly higher than groups I or IV, and group IV significantly greater than group I $(\alpha=0.01)$.

Discussion. The reason for the poor performance in the youngest rats is not known, but it is possible that the results were influenced by increased levels of growth hormone which might be present at this age. Although Winegrad et al. demonstrated enhanced $\mathrm{CO}_{2}$ production when growth hormone was added in vitro; Good$M_{A N}{ }^{10}$ showed that injection of the hormone into rats for 4 days prior to sacrifice resulted in reduced $\mathrm{CO}_{2}$ production as well as decreased fatty acid synthesis in the iso-

Carbon dioxide production from adipose tissue in rats of various Weights (results expressed as $\mu 1 \mathrm{CO}_{2}$ evolved per $100 \mathrm{mg}$ wet tissuc/h)

\begin{tabular}{lccl}
\hline Group & Weight $(g)$ & Mean $\pm \$ . \mathrm{D}$. & $\begin{array}{l}\text { No. of ex- } \\
\text { periments }\end{array}$ \\
\hline I(b and c) & $35-50$ & $11.8 \pm 5.2$ & 20 \\
II & $55-70$ & $17.4 \pm 10.4$ & 25 \\
III & $75-90$ & $34.7 \pm 9.6$ & 22 \\
IV & $150-200$ & $22.7 \pm 7.4$ & 10 \\
\hline
\end{tabular}

lated fat pad. Altschuler et al. ${ }^{11}$ suggested that the increased fatty acid release in their immature rats might also be secondary to the effects of the growth hormone. Unfortunately, no data concerning the levels of growth hormone in rats at various ages are available at present.

We have no explanation for the increased $\mathrm{CO}_{2}$ production in group III $(75-90 \mathrm{~g})$ as compared to the adult group. Neither could HAGEN et al. ${ }^{2}$ fully explain the poorer response seen in older rats (over $250 \mathrm{~g}$ ), but suggested that 'dietary or hormonal' influences were involved. Altschuler et. al."1 found a decreased tissue nitrogen content in mature rats compared to animals weighing less than $100 \mathrm{~g}$, coincident with reduced activity.

Zusammentassung. Es wurde der Einfluss von Insulin auf die $\mathrm{CO}_{2}$-Produltion im Fettgewebe unreifer Ratten mit einem Gewicht zwischen 35 und $90 \mathrm{~g}$ manometrisch bestimmt, wobei mit zunehmendem Gewicht bis zu $90 \mathrm{~g}$ eine vermehrte $\mathrm{CO}_{2}$-Produktion festgestellt werden konnte.

G. E. BACON

Departments of Pediatrics and Pharmacology,

The University of Michigan Medical Center,

Ann Arbor (Michigan, USA), June 13, 1966.

*C. Y. KRAMER, Biometrics 12,307 (1956).

- A. I. Winegrad, W. N. SHaw, F. D. W. Lukens, W.C. STavie, and A. E. RENOLd, J. biol. Chem. 234, 1922 (1959).

10 H. M. Goodman, Endoerinology 72, 95 (1963).

11 H. Altschuler, M. Lieberson, and J. J. Spitzer, Experientia 18 , 91 (1962).

\section{Identification of Steroid Hormones from Lacerta sicula Testes}

The occurrence of sex hormones in the gonadal tissue of some representatives of lower vertebrates has been reported in recent years. The analyses of the testicular tissue of marine vertebrates, namely the teleosts Salmo irideus and Cyprinus carpia', Morone labrax ${ }^{2}$. Oncorhynchus nerka ${ }^{3}$, and the elasmobranch Scyliorhinus stellaris ${ }^{4}$ have shown the presence of well-known steroid hormones. Testes and Bidder's organs of Bufo vulgaris ${ }^{5}$ also produce androgen precursors and oestrogens. Information regarding the androgenic material in Sauropsida is still lacking; therefore we have analysed the testicular tissue of the lizard Lacerta sicula.

From 400 mature animals, $35 \mathrm{~g}$ of material were obtained. The tissue was lyophilized and the free steroids extracted with organic solvents. The conjugated steroids were extracted after acid hydrolysis with $\mathrm{HCl}$ and dioxane. The phenolic steroids were separated from the neutral ones by extraction with NaOH. Neutral and phenolic fractions were purified by column and thin-layer chromatography. The identification of the steroids was obtained by means of UV-spectra, characterization of derivatives, and gas-liquid chromatography.

Neutral fraction. Both free and conjugated neutral fractions were purified on neutral alumina column, eluted with mixtures of petroleum ether-cthylacetate. The fractions were then examined on thin-layer, using silica gel $G$ as adsorbent and the mixture acetone/chloroform $(5: 95)$ as solvent system. 4 spots were detected in the free neutral extract by exposure to iodine vapour, corresponding to the $\mathrm{Rf}$ values of progesterone, androstenedione, androsterone and testosterone. The UV-spectra of the first 2 spots showed maximum absorption at $240 \mathrm{~nm}$ in absolute ethanol and $290 \mathrm{~nm}$ in concentrated sulphuric acid. Gasliquid chromatography of the eluates from thin-layer chromatography, using a Barber Colman apparatus with column packed with SE-30 $2 \%$ in Chromosorb $W$ and an argon flow of $81 \mathrm{ml} / \mathrm{min}$, confirmed the presence of progesterone in the first spot and of androstenedione in the second. By these methods it was also possible to detect $20 \beta$-hydroxypregn-4-en-3-one in the first spot and dehydroepiandrosterone and pregnenolone in the second.

I L. Galziona, Re. Accad. Sci. fis. mat., Napoli 31, 92 (1961).

2 C. Lupo and G. Chierfi, Rc. Accad. Sci. fis. mat, Napoli 34, 443 (1963).

3 D. Grajcer and D. IR. IdLer, Can. J. Biochem. Physiol. 41, 23 (1963).

4 G. ChiffFi and C. Lupo, Nature, Lond. 190, 169 (1961).

s G. Chinfri and C. Lupo, Rc. Accad. Sci. fis. mat., Napoli 30, 399 (1961). 